\title{
PENYULUHAN AGAMA BERBASIS EKONOMI KEPADA MASYARAKAT PASCA PENUTUPAN LOKALISASI DI DUSUN KALISARI BANJARSARI TRUCUK BOJONEGORO
}

\author{
M. Mulabbil Bait, M.H.I. Dkk ${ }^{1}$ \\ Institut Agma Islam Sunan Giri Bojonegoro \\ Email: rojahilman@gmail.com
}

\begin{abstract}
Abstrak
Praktek prostitusi terselubung masih banyak terjadi di terjadi di daerah eks lokalisasi. Seperti halnya di daerah eks Lokalisari Banjarsari. Cara pandang masyarakat yang memandang PSK sebagai sampah masyarakat sebenarnya menjadi salah satu faktor yang menghambat agar tercapainya harapan untuk sadar para PSK untuk keluar dari praktek prostitusi. Diperlukan kesadaran bersama (komunal) dari pasa PSK dan masyarakt yang ada disekitar eks lokalisasi untuk sama-sama menghilangkan praktek prostitusi.
\end{abstract}

Kata kunci: Prostitusi, Eks lokalisasi

\section{PENDAHULUAN}

Prostitusi merupakan hal yang sudah lama dan tua.Secara historis, prostitusi di Indonesia telah bermula sejak zaman kerajaan dahulu yang menggunakan komoditas perempuan sebagai bagian dari sistem feodal. Prostitusi biasanya lebih dominan pada perempuan sebagai pekerjanya yang lebih dikenal dengan pelacur.Pelacur adalah profesi yang menjual jasa untuk memuaskan kebutuhan seksual pelanggan yang kemudian diperhalus menjadi Wanita Tuna Sosila (WTS) ${ }^{2}$ dan kini lebih dikenal dengan sebutan Pekerja Seks Komersial $(\mathrm{PSK})^{3}$.PSK dianggap sebagai profesi menggiurkan oleh sebagian besar orang,

\footnotetext{
${ }^{1}$ Dosen IAI Sunan Giri Bojonegoro. rojahilman@gmail.com

${ }^{2}$ WTS adalah wanita yang mempunyai kebiasaan melakukan hubungan seks di luar perkawinan dengan berganti-ganti pasangan dengan maksud mendapatkan imbalan berupa uang atau barang.Kartono, 1992. 183

${ }^{3}$ Pekerja Seks Komersial dalam buku Patologi Sosial dijelaskan sebagai peristiwa memperjual-belikan badan, kehormatan, dan kepribadian kepada banyak orang untuk memuaskan nafsu seks dengan imbalan pembayaran oleh perempuan dan laki-laki. Kartini Kartono, Patologi Sosial (Bandung: Raja Grafindo Persada, 2009), 5. Sedangkan Mudjijono menyebutnya PSK sebagai pekerjaan sehari-hari memuaskan nafsu seksual laki-
} 
karena mampu mendatangkan uang yang cukup lumayan, sehingga kegiatan melacur ini menjadi pilihan bagi sebagian perempuan yang dihimpit kesulitan ekonomi dengan secara suka rela.

Beberapa perempuan PSK menikmati pekerjaannya ini, yang biasanya pelayanannya dalam bentuk menyewakan tubuhnya.Oleh itu, di kalangan masyarakat Indonesia, pelacuran dipandang negatif dan para pekerjanya dianggap sebagai sampah masyarakat atau disebut "sundal".Hal ini di samping karena mayoritas bangsa Indonesia adalah masyarakat religius, juga menunjukkan bahwa betapa pelacuran itu begitu buruk dan menyebabkan rendahnya harga diri seseorang tersebut. Zaman dahulu seorang pelacur tertangkap akan digundul, diusir dari komunitas masyarakat karena dianggap telah menodai agama, melanggar hukum dan oleh sebab itu ada yang kemudian diseret ke pengadilan. Hingga era kontemporer ini prostitusi tidak pernah surut, masih terus ada di mana-mana dan tetap dipandang penuh kehinaan.Karena itu prostitusi termasuk suatu masalah sosial yang sulit dikendalikan oleh negara di manapun itu, baik di negara berkembang maupun di negara maju. Walaupun sudah diperangi dan dilarang, namun tetap terus akan ada. Latar belakang sosial ekonomi yang paling banyak mendorong seorang untuk bekerja di tempat protistusi.

Walaupun kadang menjadi PSK bukan semata-mata untuk mencari nafkah, tetapi terdapat berbagai faktor hingga mereka menjerumuskan diri pada pekerjaan ini.Awalnya, mereka terjun ke dunia prostitusi disebabkan beberapa hal, di antaranya disharmoni kehidupan rumah tangga.Karena tidak lagi merasakan kenyamanan tinggal di rumah bersama orang tua, mereka lantas melarikan diri dari rumah dan masuk dunia prostitusi.Kelompok berikutnya adalah PSK yang diperjual-belikan (human trafficking).Saat masih anak-anak, mereka dijual kepada orang salah yang akhirnya membawa mereka ke sebuah tempat pelacuran.Selain itu ada sebagian dari mereka yang frustrasi setelah putus dengan pacarnya, hingga akhirnya menyeret dirinya ke lembah prostitusi.

Meski latar belakang para PSK berbeda-beda, akan tetapi pada akhirnya persoalan ekonomi menjadi tujuan utama mereka dalam melakukan kegiatan prostitusi. Tidak heran, ketika tempat prostitusi ditutup, bukan hanya tempat prostitusi kategori kelas kecil, tempat prostitusi berkelas nasional -seperti pelacur di Dolly Surabaya- juga merasa keberatan dengan alasan ekonomi. Hal sama juga terjadi pada pelacur yang sebelumnya praktik di lokalisasi

laki atau siapa saja yang sanggup memberikan imbalan tertentu yang biasa berupa uang atau benda beharaga lainnya. Mudjijono, Sarkem: Reproduksi Soial Pelacuran (Yogyakarta: Gadjah Mada Pres, 2005), 9. 
Gandul Tuban, mereka keberatan tempat kerjanya ditutup, karena sehari-sehari menjadi sumber penghasilan bagi pelacur, mucikari, dan warga sekitar ${ }^{4}$.

Pada umumnya, wanita PSK tersebut bekerja dan menjalani hidupnya di lingkungan lokalisasi, serta berada jauh dari keluarganya seperti kebanyakan PSK yang berada di Kalisari adalah berasal dari luar kota. Lokalisasi secara resmi diatur oleh pemerintah daerah. Dalam hal pengaturan lokalisasi oleh pemerintah, dimaksudkan agar praktik-praktik prostitusi tidak merajalela di setiap sudut kota sehingga mengotori keindahan kota. Dari segi pendidikan, hal pemusatan praktik prostitusi juga dimaksudkan agar jauh dari lingkungan masyarakat awam dan tidak mempengaruhi pola perilaku anak-anak di bawah umur. Namun, alih-alih untuk tujuan mengatur, lokasisasi Kalisasi justru bercampur dengan lingkungan warga setempat.Dimana akhirnya ditutup secara resmi pada 2001.

Meskipun sudah ditutup, kehidupan masyarakat Kalisari tidak bisa bebas dari kegiatan haram tersebut.Pada kenyataannya rumah-rumah penduduk ada beberapa yang memang sengaja masih disewakan untuk tujuan kegiatan haram itu.Para lelaki hidung belang juga masih berdatangan siang atau malam. Anehnya, masyarakat sekitar tetap enjoy dan seakan tidak merasa jijik dengan kehidupan yang bercampur dengan perzinaan itu. Penduduknya tetap menjalankan aktivitas keagamaan seperti biasa.Ada mushalla yang setiap waktu mengumandangkan azan, ada pengajian rutin Jum'at Wage dan untuk ibu-ibunya ada tahlil rutin sebulan 2 kali termasuk ada Majelis taklim al-Jadid.

Lantas bagaimana kehidupan keluarga di sekitar komplek lokasisasi Kalisari, bukankah mereka juga mempunyai anak yang sepatutnya dijauhkan dari kehidupan yang haram. Terlebih prostitusi bukan saja dipandang negatif, tetapi juga punya dampak buruk bagi keberlangsung kehidupan masyarakat.Ironisnya masyarakat di sini tidak menghiraukan hal itu dan tetap menjalankan aktifitasnya seperti biasa.Bahkan sebagian besar malah terlihat ikut terlibat menyemarakkan kegiatan haram tersebut.Misalnya beberapa warga yang meyewakan rumahnya tidak berusaha untuk menyembunyikan pekerjaannya dari anakanaknya. Bahkan kepada masyarakat secara umum, mereka tidak malu seakan itu sah-sah saja dengan tanpa ada rasa sedikit pun bersalah.

${ }^{4}$ Mujib Ridlwan,Resiliensi Berbasis Religi Bagi Mantan PSK dan Mucikari Pasca Penutupan Lokalisasi Gandul Tuban, Marâji': Jurnal Studi Keislaman, 2015, vol. 2, no. 1. ISSN: 2406-7636 


\section{PEMBAHASAN}

\section{A. Gambaran Umum Lokasi Pengabdian}

Desa Banjarsari, lokasi yang dipilih oleh penulis untuk melakukan penelitian dan pengabdian kepada masyarakat, merupakan salah satu desa di wilayah kecamatan Trucuk Kabupaten Bojonegoro. Penduduk desa Banjarsari secara kasat mata merupakan penduduk yang agamis. Hal ini dapat dilihat dari banyak dijumpai masjid, musholla dan lembaga keagamaan berdiri kokoh di wilayah tersebut. Majlis ta'lim dan penyuluhan agama juga marak dilakukan. Namun demikian, di desa Banjarsari, tepatnya di dusun Kalisari, terdapat satu tempat untuk menyalurkan kebutuhan biologis yang terkenal dengan sebutan Lokalisasi Kalisari. Lokalisasi ini berdiri sejak tahun 1979 berawal dari penglokalisiran beberapa tempat mesum yang menyebar di Kabupaten Bojonegoro ${ }^{5}$.

Lokalisasi Kalisari terdiri dari 3 (tiga) RT (Rukun Tetangga) yaitu RT 11, 12 dan 13 dengan jumlah penduduk 350 orang.

Tanah tempat Lokalisasi Kalisari ini berada merupakan tanah negara. Selama \pm (kurang lebih) 19 tahun, lokalisasi ini beroperasi, hingga akhirnya pada tahun 1998, yang saat itu dipimpin oleh Bupati M. Atlan (alm) ${ }^{6}$, Lokalisasi ini ditutup ${ }^{7}$. Pasca ditutupnya Lokalisasi Kalisari sampai saat ini (berlangsungnya penelitian dan pengabdian kepada Masyarakat), kehidupan malam dan aktivitas penyaluran kebutuhan biologis tetap berjalan, meskipun dilakukan secara diam-diam dan tidak semarak sebelum dilakukan penutupan. Ironis memang,tetapi itulah fakta di lapangan.

\section{B. Kondisi Saat Ini Masyarakat Dampingan}

Pasca ditutupnya Lokalisasi Kalisari sampai saat ini (berlangsungnya penelitian dan pengabdian kepada Masyarakat), kehidupan malam dan aktivitas penyaluran kebutuhan biologis tetap berjalan, meskipun dilakukan secara diam-diam dan tidak semarak sebelum dilakukan penutupan. Ironis memang,tetapi itulah fakta di lapangan.

\footnotetext{
${ }^{5}$ Tempat-tempat mesum di kabupaten Bojonegoro sebelum dilokalisir berada di desa Bayeman, Sroyo, Kapas dan Ngablak.

${ }^{6}$ Hasil wawancara dengan salah seorang tokoh masyarakat dusun Kalisari pada hari Rabu, 31 Agustus 2016.

${ }^{7}$ Penutupan Lokalisasi Kalisari terjadi dua kali. Pertama pada tahun 1998 dan penutupan yang kedua terjadi pada tahun 2001. Penutupan pada tahun 2001 ini yang diklaim sebagai penutupan yang resmi.
} 
Tetap bergeliatnya kehidupan malam dan aktivitas penyaluran kebutuhan biologis di eks Lokalisasi Kalisari ${ }^{8}$, sebagaimana dituturkan oleh tokoh masyarakat dusun Kalisari, disebabkan karena beberapa faktor. Salah satunya adalah kurang adanya kepedulian dari pemerintah kabupaten Bojonegoro saat itu dalam mengentas kehidupan para pekerja seks komersial (PSK), mucikari dan warga yang menggantungkan hidupnya dari eks Lokalisasi tersebut dari lembah kehinaan. Oleh karena itu, diperlukan upaya yang serius dan sinergitas dari berbagai lapisan masyarakat dalam pengentasan kehidupan para (PSK), mucikari dan warga yang menggantungkan hidupnya dari eks Lokalisasi Kalisari.

\section{Kondisi Yang diharapkan}

Sebagaimana telah diuraikan di sub bab kondisi dampingan bahwa kehidupan malam dan aktivitas penyaluran kebutuhan biologis di eks Lokalisasi Kalisari tetap bergeliat meskipun secara resmi telah ditutup pada tahun 2001. Kondisi ini sungguh memprihatinkan dan memotivasi peneliti untuk setidaknya ikut memberi "warna yang berbeda" kepada penduduk eks Lokalisasi Kalisari dengan melakukan pendampingan secara intens. Hal ini dilakukan dengan harapan penduduk eks Lokalisasi Kalisari yang semula berprofesi baik sebagai PSK, mucikari, tukang parkir, penjual makanan dan minuman maupun profesi yang lain di eks Lokalisasi Kalisari dapat beralih profesi yang lebih bermartabat. Untuk jangka panjang, diharapkan eks Lokalisasi Kalisari benar-benar bersih dari praktek prostitusi.

\section{Strategi Pelaksanaan}

Untuk mewujudkan harapan eks Lokalisasi Kalisari bersih dari praktek prostitusi diperlukan aksi nyata berupa:

1. Penyuluhan Agama Murni

Pengabdian kepada penduduk eks Lokalisasi Kalisari dalam bentuk penyuluhan agama sangat diperlukan, karena agama merupakan pondasi utama dalam membentuk masyarakat yang bermartabat dan beradab. Di samping itu, pola semacam ini secara akademis merupakan inplementasi nilai-nilai keilmuan dosen yang mengemban fungsi Tri Dharma Perguruan Tinggi.

2. Santunan Anak Usia Sekolah dan Fakir Miskin

${ }^{8}$ Bahkan pada tahun 2013 Pemerintah Kabupaten Bojonegoro sempat akan membuka kembali dan melegalkan Lokalisasi Kalisari. Kebijakan untuk membuka kembali dan melegalkan Lokalisasi Kalisari didasarkan oleh argumen bahwa Lokalisasi ibarat kotoran yang senantiasa ada mengiringi keberadaan dunia. Lihat: http://www.lensaindonesia.com/2013/01/01/ditutup-12-tahun-lokalisasi-kalisari-bakal-dibuka-lagi.html dan http://blokbojonegoro.com/read/article/20111222/komisi-c-lokalisasi-kalisari-perlu--dilegalkan.html. (diakses pada hari Rabu,31 Agustus 2016). 
Pemberian santunan anak usia sekolah dan fakir miskin merupakan bentuk kepedulian kepada orang yang membutuhkan di satu sisi. Di sisi yang lain, dengan memberikan santunan kepada anak yatim diharapkan penduduk eks Lokalisasi Kalisari tertarik simpatinya kaena merasa telah terbantu. Simpati penduduk eks Lokalisasi Kalisari sangat dibutuhkan untuk menciptakan kehidupan yang lebih religius

3. Penyuluhan Agama Berbasis Ekonomi

Pengabdian kepada penduduk eks Lokalisasi Kalisari dalam bentuk penyuluhan agama berbasis ekonomi ini sangat penting karena di samping menciptakan kehidupan religius, melalui pengabdian masyarakat ini dapat terbentuk kemandirian ekonomi bagi penduduk eks Lokalisasi Kalisari, tanpa harus menggantungkan hidupnya dari praktek prostitusi.

Bentuk penyuluhan agama berbasis ekonomi yang akan dilakukan adalah:

a. Mengadakan kursus tataboga dan kerajinan tangan kepada para wanita dewasa dan remaja putri yang putus sekolah secara gratis.

b. Memberikan modal usaha berupa kambing.

c. Pemberian Santunan kepada anak-anak usia sekolah dan fakir miskin

Pengabdi memutuskan untuk melakukan 3 (tiga) bentuk penyuluhan agama berbasis ekonomi di atas setelah melakukan pemetaan terhadap bakat dan minat masyarakat Kalisari dan sekitarnya.

\section{E. Kajian Teori}

Teori yang digunakan dalam pengabdian ini adalah:

1. Industrialisasi dan Perubahan Keluarga

Menurut Ronalt Lippit yang dikutip oleh Merrill \& Elliot bahwa pendorong bagi perubahan Keluarga adalah berkembangnya kebudayaan materi, tingkat penemuan dan inovasi teknologi, perbaikan fasilitas transportasi dan komunikasi dan meluasnya industrialisasi dan urbanisasi.

Dengan adanya perubahan-perubahan ini, masalah-masalah yang paling umum yang kita jumpai adalah terjadinya perkembangan-perkembangan dalam masyarakat, yang salah satunya adalah perubahan masyarakat dari masyarakat agrarian yang tradisional ke masyarakat yang modern. Konsekuensi daripada perubahan ini selanjutnya adalah pengaruh terhadap organisasi keluarga yakni perubahan dari extended family menjadi nuclear family. 
Pengabdi menggunakan teori ini untuk menganalisis faktor yang melatarbelakangi PSK dan warga yang menggantungkan hidupnya di eks Lokalisasi Kalisari memilih mencari pengasilan di tempat prostitusi.

2. Teori Dramaturgi ${ }^{9}$

Erving Goffman, lahir di Alberta, Canada pada 11 Juni 1922. Mendapat gelar S1 dari Univ. Toronto dan menerima gelar doctor dari Univ. Chicago.Beliau wafat pada tahun 1982 ketika sedang mengalami kejayaan sebagai tokoh sosiologi dan pernah menjadi professor dijurusan sosiologi Univ. Calivornia Barkeley serta ketua liga Ivy Univ. Pennsylvania. Erving Goffman, dianggap sebagai pemikir utama terakhir Chicago asli (Travers, 1922: Tselon, 1992); Fine dan Manning (2000) memandangnya sebagai sosiolog Amerika paling berpengaruh di abad 20. Antara 1950-an dan 1970-an Goofman menerbitkan sederetan buku dan esai yang melahirkan analisis dragmatis sebagai cabang interaksionisme simbolik. Walau Goffman mengalihkan perhatiannya di tahun-tahun berikutnya, ia tetap paling terkenal karena teoridramtugisnya.

Pernyataan paling terkenal Goffman tentang teori dramaturgis berupa buku Presentation of Self in Everyday Life, diterbitkan tahun 1959.Secara ringkas dramaturgis merupakan pandangan tentang kehidupan sosial sebagai serentetan pertunjukan drama dalam sebuah pentas. Istilah Dramaturgi kental dengan pengaruh drama atau teater atau pertunjukan fiksi diatas panggung dimana seorang aktor memainkan karakter manusia-manusia yang lain sehingga penonton dapat memperoleh gambaran kehidupan dari tokoh tersebut dan mampu mengikuti alur cerita dari drama yang disajikan.

Dalam Dramaturgi terdiri dari Front stage (panggung depan) dan Back Stage (panggung belakang). Front Stage yaitu bagian pertunjukan yang berfungsi mendefinisikan situasi penyaksi pertunjukan. Front stage dibagi menjadi 2 (dua) bagian, Setting yaitu pemandangan fisik yang harus ada jika sang aktor memainkan perannya. Dan Front Personal yaitu berbagai macam perlengkapan sebagai pembahasa perasaan dari sang aktor. Front personal masih terbagi menjadi dua bagian, yaitu Penampilan yang terdiri dari berbagai jenis barang yang mengenalkan status sosial aktor. Dan Gaya yang berarti mengenalkan peran macam apa yang dimainkan actor dalam situasi tertentu. Back stage

\footnotetext{
${ }^{9}$ George Ritzer, Teori Sosiologi: dari Sosiologi Klasik sampai Perkembangan Terakhir Postmoderrn, Jogjakarta: Pustaka Pelajar, Edisi VIII, 2012, hlm 637-640.
} 
(panggung belakang) yaitu ruang dimana disitulah berjalan skenario pertunjukan oleh "tim" (masyarakat rahasia yang mengatur pementasan masing-masing aktor).

Relevansi teori dramaturgi dengan pengabdian masyarakat ini adalah perilaku seseorang bersifat fluktuatif, bahkan tidak jarang perilaku itu hanya sisi luar. Hal ini seperti tampak dalam keseharian kehidupan para PSK. Tidak sedikit para PSK yang aktif mengikuti kegiatan keagamaan.

\section{Teori Pilihan Rasional}

James S. Coleman menerima gelar Bachelor of Science dari Universitas Purdue tahun 1949 dan bekerja sebagai ahli kimia untuk Eastman Kodak sebelum masuk ke departemen sosiologi Unversitas Colombia tahun 1951. Teori pilihan rasional ${ }^{10}$ ini umumnya berada di pinggiran aliran utama teori sosiologi, namun melalui Coleman, teori ini menjadi salah satu teori "hebat" dalam sosiologi masa kini. Teori tindakan rasional tersebut mengarahkan kepada dua hal yaitu aktor dan sumber daya.

Pengabdi menggunakan teori ini sebagai dasar dalam penentuan strategi aksi, sehingga tepat sasaran dan efektif.

\section{Teori Asset Based Community development (ABCD)}

Teori Asset based community developmentadalah suatu konsep pengembangan masyarakat yang didasarkan pada aset lokal yang terdapat di suatu wilayah. Aset tersebut dikembangkan sehingga dapat memecahkan masalah-masalah yang terdapat di wilayah itu.

Pengabdi menggunakan teori ini sebagai dasar dalam penentuan strategi aksi, sehingga tepat sasaran dan efektif.

\section{F. Gambaran Kegiatan}

Kegiatan yang dilakukan selama proses penyuluhan berbasis ekonomi di Dusun Kalisari Desa Banjarsari Trucuk Bojonegoro meliputi dua kegiatan besar, yaitu penyuluhan dan pelatihan.

1. Penyuluhan agama murni yaitu pemberian materi agama ${ }^{11}$ yang meliputi fikih ${ }^{12}$ (hukum Islam)dan pembekalan spiritual (tasawuf ${ }^{13}$ ) setiap 1 (satu) minggu sekali, pembacaan yasin dan tahlil bersama tiap malam jum'at 2 (dua) minggu sekali.

\footnotetext{
${ }^{10}$ George Ritzer, Teori Sosiologi: dari Sosiologi Klasik sampai Perkembangan Terakhir Postmoderrn (Jogjakarta: Pustaka Pelajar, Edisi VIII 2012), hlm 640-761.

${ }^{11}$ Materi penyuluhan agama menggunakan kitab al-Fiqh al-Manhaji 'ala Madzhab al-Imam al-Syafi' $i$ karya DR. Musthofa Dib Bugho (materi Fikih) dan kitab Minhaj al-'Abidin karya Imam Ghzali (materi Tasawwuf).
} 
2. Penyuluhan agama berbasis ekonomi yang meliputi:

a. Mengadakan kursus tataboga dan kerajinan tangan

Kegiatan kursus tata boga dengan mendatangkan koki atau juru masak yang berpengalaman, hal ini dilakukan dengan harapkan pemberian kursus dilakukan oleh tenaga yang ahli dibidangkan. Setelah mengikuti kursus tata boga ini diharapkan warga khususnya peserta kursus dapat memanfaatkan keahlian yang didapatkannya untuk memperoleh pengasilan lain. Materi yang disampaikan dalam kursus tata boga ini meliputi pembuatan kue basah dan kue kering.

b. Santunan kepada anak usia sekolah dan fakir miskin.

Santuan kepada anak usia sekolah dan fakir miskin ini diberikan bersamaan dengan kegiatan penyuluhan agama yang ketiga. Dengan dasar agar anak usia sekolah dan fakir miskin yang dulunya tidak berminat dengan penyuluhan menjadi tertarik dengan penyuluhan. Agar santunan yang dilaksanakan tepat sesuai dengan sasaran, pengabdi melibatkan ketua RT setempat (RT 11, RT 12, dan RT 13) untuk memilih warga di RT mereka masing-masing yang berhak untuk menerima santunan.

c. Memberi modal usaha berupa kambing

Pemberian modal berupa hewan ternak (kambing) diberikan kepada enam orang yang sudah dipilih oleh pengabdi atas usulan dari warga.Kambing dipilih karena merupakan salah satu usaha yang cukup menjanjikan, disamping perawatannya sangat mudah, ternak kambing juga memiliki potensi sebagai kompoten usaha tani yang penting di berbagai agroekosistem. Adaptasi ternak kambing relative lebik baik dibandingkan dengan hewan ternak lain. Para penerima kambing ada juga yang menerima santunan fakir miskin. Penentuan siapa yang berhak menerima berdasarkan hasil diskusi dengan ketua RT setempat.

\section{G. Dinamika Keilmuan}

Setelah diadakan penyuluhan agama murni dengan materi fikih (hukum Islam) dan pembekalan spiritual setiap satu minggu sekali, pembacaan yasin dan tahlil bersama tiap malam jum'at 2 minggu sekali, masyarakat yang dulunya terjebak lembah hitam dunia prostitusi sedikit demi sedikit mulai sadar bahwa yang dilakukan selama ini adalah perbuatan yang haram dan telah menyimpang dari norma agama.

\footnotetext{
${ }^{12}$ Materi yang disampaikan: bersuci, najis, hadats kecil dan besar, sholat, puasa, dan zakat.

${ }^{13}$ Materi yang disampaikan terkait karakteristik surga dan penghuninya, rahmat, taubat, zina, syukur, keutamaan bekerja yang halal, dampak bekerja yang haram, malu dan tawakal kepada Allah.
} 
Penyuluhan berikutnya yaitu penyuluhan agama berbasis ekonomi yang meliputi :

1. Mengadakan kursus tataboga ( membuat kue kering dan kue basah) dan kerajinan tangan

2. Santunan kepada anak usia sekolah dan fakir miskin

3. Memberi modal usaha berupa kambing. Kambing dipilih dengan berbagai pertimbangan. Salah satunya karena kambing merupakah salah satu hewan ternak yang paling mudah beradaptasi dan peling mudah untuk dikembangbiakkan dibandingkan hewan ternak lain

Dengan diadakannya kegiatan tersebut terbukti bahwa hasil evaluasi penyuluhan agama murni dan penyuluhan agama berbasis ekonomi memperoleh hasil yang baik dengan Indikator keberhasilan sebagai berikut:

1. Peserta penyuluhan mampu menguasai teori tentang fikih (hukum Islam).

2. Peserta mampu mengaplikasikan hukum Islam dalam kehidupan sehari-hari.

3. Peserta mampu menguasai teori tentang pembekalan spiritual (tasawuf).

4. Peserta mampu mengembangkan potensi diri.

5. Peserta dapat mengaplikasikan ilmu yang diperoleh dari pelatihan dalam hal ini kursus tataboga dan kerajinan tangan.

\section{H. Teori Yang Dihasilkan Dari Pendampingan}

Selama melaksanakan penyuluhan dan pelatihan kepada masyarakat di dusun Kalisari Desa Banjarsari Kecamatan Trucuk Bojonegoro, tim pengabdi menemukan bahwa praktek prostitusi dikawasan eks lokalisasi kalisari lebih didominasi oleh para pendatang (PSK pendatang) bukan warga asli dari kalisari sendiri. Menurut keterangan dari ketua RT 13, warga sekitar menyebutkan dengan istilah "Bus Malam", istilah ini berdasarkan aktifitas mereka yang pada saat malam hari mereka datang dan akan pergi saat pagi hari.

kesadaran pada eks PSK tidak selalu bebarengan dengan kesadaran masyarakat untuk membantu para eks PSK agar para eksPSK bisa kembali kejalur yang menurut norma-norma masyarakat dianggap benar. Sehingga ketika para PSK punya keinginan untuk sadar seolaholah tidak ada orang yang membantu mereka untuk sadar.

Masyarakat sekitar lokalisasi sepatutnya tidak menjauhi para PSK dan eks PSK karena mereka seharusnya mendapatkan perhatian positif dari masyarakat, bukan hanya perhatian negatifnya saja seperti dalam teori Teori Labelling, teori ini dipelopori oleh Edwin M. Lemerd yang berpendapat bahwa seseorang yang telah melakukan penyimpangan pada tahap primer (pertama) kemudian masyarakat mencapnya sebagai tindakan menyimpang ${ }^{14}$.

14Agung Raharjo, Buku Kantong Sosiologi SMA IPS. Yogyakarta: Pustaka Widyatama, 2009, hlm, 26. 
Kesadaran yang hendak muncul dari para eks PSK sering terbentur dengan stigma yang sudah melekat di masyarakat.Bahwa seseorang yang sudah terjun di dunia prostitusi adalah sampah yang harus dijauhi dan sampai kapanpun mereka tetaplah sampah masyarakat, sehingga ketika seorang PSK ingin keluar dari dunia prostitusi membutuhkan waktu yang sangat lama untuk mengembalikan citranya kembali sebagai manyarakat pada umumnya.

Perlu dukungan dari stakeholder dan masyarakat dalam mengembalikan mereka selayaknya manusia biasa yang bisa diterima oleh masyarakat dalam berbagai hal.Seperti pembinaan moral, pemberian keterampilan dan lapangan pekerjaan.Agar mereka dapat meninggalkan dunia prostitusi.

Ketika masyarakat hendak menyadarkan para Eks PSK agar mereka tidak terjerumus lagi ke dalam lembah prostitusi maka diperlukan yang namanya kesadaran komunal (teori kesadaran komunal). Maksud dari teori kesadaran komunal disini adalah untuk menyadarkan para minoritas yang ada di suatu kelompok masyaraka diperlukan dukungan dari masyarakat sekitar.Teori yang ditemukan dilapangan ini berbeda dengan teori kesadaran kolektif yang dikemukakan oleh Durkheim.Durkheim dalam teori kolektifnya lebih mendekatkan kepada kasadaran bersama norma-norma yang berlaku dimasyarakat. Sedangkan kesadaran komunal yang ditemukan dalam pengabdian ini lebih kepada kesadaran bersama untuk saling membantu satu sama lain dalam suatu kelompok masyarakat.

\section{Diskusi Data}

Selama terlaksana kegiatan penyuluhan dan pengabdian kepada masyarakat ini ditemukan beberapa data. Diantaranya:

1. Praktek prostitusi tetap berjalan dengan sembunyi-sembunyi.

2. Keinginan sadar para eks PSK tidak selalu berbanding lurus dengan masyarakat sekitar lokasi yang masih menganggap mereka sampah masyarakat dan patut untuk dijauhi.

3. Banyak orang yang enggan untuk memberikan penyuluhan dilokasi, Padahal beberapa warga sana sangat berharap adanya penyuluhan, meskipun yang lain menolak adanya penyuluhan.

4. Kemiskinan memang tidak bisa dipungkiri selalu menjadi penyebab akan adanya penyimpangan social.

5. Keterbatasan keahlian yang bisa menghasilkan tambahan penghasilan juga menjadi penyebab masih saja ada yang membuka praktek prostitusi.

6. Masyarakaat sangat menerima jika ada pelatihan-pelatihan. 


\section{J. Follow Up}

Beberapa tindak lanjut dari data yang ditemukan di lokasi pengabdian:

1. Kegiatan penyuluhan ini akan tetap berjalan sampai beberapa pertemuann kedepan. Dengan harapanan praktek prostitusi dengan sembunyi-sembunyi akan berkurang secara perlahan-lahan

2. Penyuluhan dalam bentuk ceramah tidak hanya diberikan kepada pada eks PSK saja, para masyarakat sekitar juga diundang agar mereka juga bisa sadar bahwa praktek prostitusi bukan hanya kesalahan dari para PSK saja, akan tetapi juga merupakan beban bersama untuk segera diselesaikan.

3. Berusaha memberikan pengertian kepada masyarakat bahwa eks PSK bukanlah musuh yang harus dijauhi. Akan tetapi mereka harus sering didekati dan diberikan pengertian agar segera keluar dari praktek prostitusi.

4. Pemberian hewan ternak kambing sebagai upaya untuk memperoleh hasil tambahan. Ternak kambing dipilih karena kambing hewan ternak yang paling mudah beradaptasi dan mudah untuk dikembangbiakkan. Hewan ternak yang sudah diberikan akan dipantau beberapa bulan kedepan supaya hewan tersebut tidak dijual.

5. Pelatihan membuat kerajinan dan tataboga yang sudah diberikan akan dibantu dalam penjualan produknya.

\section{Simpulan dan Penutup}

Masih banyak para Pekerja Seks komersial eks lokalisai kalisari yang membuka praktek prostitusi secara sembunyi-sembunyi.Sehingga meskipun lokalisasi kalisari sudah ditutup oleh pemerintah kabupaten bojonegoro pada tahun 2001.pada kenyataannya, praktek terselubung prostitusi masih tetap berjalan dengan dalih tidak ada pekerjaan lain selain pekerjaan lama mereka tersebut. Praktek prostitusi berjalan dengan model para PSK menjajakan dirinya dan warga sekitar menyewakan kamar-kamar untuk traksaksi tersebut. Dalam prakteknya, para PSK yang menjajakan diri di Dusun Kalisari lebih didominasi oleh PSK pendatang atau yang lebih dikenal dengan "Bus Malam" penyebutan ini berdsarkan aktifitas mereka yang hanya ada pada malam hari dan akan pergi saat siang hari. Sedangkan para PSK yang asli dari warga Dusun kalisari jumlahnya hanya tinggal beberapa orang saja.Untuk membersihkan eks lokalisai kalisari dari praktek prostitusi tidak bisa hanya mengandalkan dari warga lokal, tetapi juga harus ada partisipasi dari stakeholder dan warga sekitar dan ada dikawasan eks lokalisasi kalisari. 
Ekonomi dan minimnya kesadaran akan bahaya prostitusi dari sisi kesehatan dan agama menjadi faktor lain dari praktek prostitusi terselubung di eks Lokalisasi Kalisari. Kesadaran para eks PSK tidak berbanding lurus dengan kesadaran yang muncul dari masyarakat untuk membantu para Eks PSK untuk hidup normal selayaknya masyarakat pada umunya.

Supaya tercipta perubahan kebaikan bersama dalam masyarakat diperlukan adanya kesadaran komunal dalam masyarakat. Hal ini dengan alasan bahwa keinginan untuk berubah menjadi lebih baik seorang PSK jika tidak didukung oleh masyarakat maka akan mustahil bisa tercapai.

Kesadaran komunal yang diperlukan tidak harus berupa tindakan, bisa berupa sikap dan cara pandang kepada para PSK dan eks PSK. Cara pandang yang memandang PSK dan eks PSK sebagai sampah masyarakat yang harus dijauhi harus dirubah dengan memandang bahwa PSK dan eks PSK adalah anggota masyarakat seperti yang lainnya akan tetapi mereka perlu mendapatkan perhatian khusus. Perhatian khusus yang dimaksud adalah perhatian agar mereka bisa sadar.

Penyuluhan berbasis ekonomi yang dilakukan selama kegiatan pengabdian di Dusun Kalisari Desa Banjarsari Kecamatan Trucuk Kabupaten Bojonegoro bertujuan selain untuk membangun pemahaman agama dan meningkatkan spiritualitas masyarakat sekitar juga untuk membangun kemandirian ekonomi.

Pengabdian ini masih belum sempurna dan perlu pembenahan dibeberapa aspek.Diperlukan pengabdian masyarakat secara rutin dengan jangka yang panjang untuk bisa merubah tradisi yang ada dimasyarakat. Karena untuk merubah cara pandang masyarakat tidak bisa dilakukan dalam waktu singkat.

Respon masyarakat setelah mengetahui program kerja dari pengabdian ini juha sangat positif. Diharapkan aka nada pengabdian-pengabdian lain di lokasi yang sama dengan model pelatihan-pelatihan yang lain seperti, menjahit, otomotif, dan elektronik.

\section{Daftar Pustaka}

Goleman, Daniel, Emotional Intelligence Why it Can Matter More Than IQ, New York: Bantam Books, 1996. http://blokbojonegoro.com/read/article/20111222/komisi-c-lokalisasi-kalisari-perlu-dilegalkan.html. 
http://www.lensaindonesia.com/2013/01/01/ditutup-12-tahun-lokalisasi-kalisari-bakaldibuka-lagi.html

Imam Ghazali, Minhaj al-'Abidin

Mudjijono, Sarkem: Reproduksi Soial Pelacuran ,Yogyakarta: Gadjah Mada Pres, 2005.

Musthofa Dib Bugho, al-Fiqh al-Manhaji 'ala Madzhab al-Imam al-Syafi'i

Raharjo, Agung, Buku Kantong Sosiologi SMA IPS. Yogyakarta: Pustaka Widyatama, 2009.

Ridlwan, Mujib, Resiliensi Berbasis Religi Bagi Mantan PSK dan Mucikari Pasca Penutupan Lokalisasi Gandul Tuban, Marâji‘: Jurnal Studi Keislaman, 2015, vol. 2, no. 1. ISSN: 2406-7636

Ritzer, George, Teori Sosiologi: dari Sosiologi Klasik sampai Perkembangan Terakhir Postmoderrn, Jogjakarta: Pustaka Pelajar, Edisi VIII, 2012 